The ILO's Safety and Health in Mines Convention: Reframing the Scope of Obligations for a Sustainable World

\title{
Jeffrey Hilgert*
}

\begin{abstract}
:
On March 23, 2015 the Turkish government ratified ILO Convention No. 176, the international labour convention concerning occupational safety and health in mines. This multilateral treaty will enter into force for Turkey in 2016. After a lengthy advocacy campaign that received renewed attention after major disasters in the mining industry, more attention is being paid to the implementation of this important ILO convention. Postratification application of the convention in the unique Turkish context requires revisiting the obligations of the convention itself. Whether the convention becomes an empty promise to Turkish mine workers or a living document for the protection of worker safety and health remains an open question. Recent recommendations by an ILO technical assistance project raise important questions about the scope of Convention No. 176 and the need for stronger efforts by the Turkish state to achieve reform in the coal mining industry. This article discusses the ILO's Safety and Health in Mines Convention in light of recent ILO technical assistance work in Turkey. It outlines arguments in favor of a more expanded legal interpretation of the obligations of Convention No. 176 in light of dangerous business practices in the coal mining industry and in light of the global community's new international consensus on sustainable development.
\end{abstract}

Keywords: Safety and health, human rights, mine workers, international labour standards, sustainability

*Assistant Professor in the School of Industrial Relations (ÉRIUM), University of Montreal, jeffrey.hilgert@umontreal.ca 
Jeffrey Hilgert

\section{Introduction}

Turkey has made a concerted effort in recent years to prioritize the protection of occupational safety and health. On March 23, 2015, Turkey took another step in this direction with the ratification of the Safety and Health in Mines Convention. ${ }^{1}$ This important ILO international labour standard has been called the Charter to protect mine workers health and safety. ${ }^{2}$ The obligations of Convention No. 176, however, pose unique challenges for the Turkish state given the nature of the Turkish extractive sector and, more specifically, the unique industrial structure of the domestic coal mining industry in Turkey. The ILO is addressing these obstacles through tripartite social dialog (unions, employers and the government), but recent recommendations highlight the obstacles facing the protection of workers in Turkey's coal mines, as well as the obstacles facing Convention 176 in general given the international community's new global consensus on sustainability, fighting climate change, and low-carbon energy policies. These obstacles in turn raise questions about the scope of the obligations of the Safety and Health in Mines Convention.

The ratification of the Safety and Health in Mines Convention follows a ten-year movement in which the Turkish state has advocated improving occupational safety and health protections, adopting strong language and taking a leadership role to promote worker health and safety. This movement includes ratification of the Safety and Health in Construction Convention No. $167,{ }^{3}$ hosting the XIX World Congress on Occupational Safety and Health in Istanbul in $2011,{ }^{4}$ advocating the Istanbul Declaration of Safety and Health at Work which states that worker safety and health is a human right, ${ }^{5}$ and becoming a party to another key convention on safety and health since 2005, the Occupational Safety and Health Convention No. 155, one primary ILO conventions on occupational safety and health. ${ }^{6}$

Whether these efforts move beyond paper and are enough to improve working conditions onthe-ground is the open question. This is the task facing the Turkish state's application of the Safety and Health in Mines Convention. The ILO's supervisory system is also involved in the monitoring each party's compliance with the convention in both law and practice. The unique nature of the coal mining industry in Turkey presents several unique challenges. As one of the most dangerous industries for workers in Turkey and among the most dangerous mining industries in the world, ${ }^{7}$ ILO technical assistance efforts have identified the structure of the Turkish coal mining industry itself and its business contracting arrangements as possible obstacles to worker protection. The unique Turkish case thus illustrates the complex questions of compliance that can result under the ILO's Safety and Health in Mines Convention. This article discusses the issues of compliance that face Turkey under this ILO convention. In the case of Turkey, the actions required to satisfy the obligations of the Safety and Health in Mines Convention likely require much larger measures than just legal enactments on workplace rights. What is needed is a comprehensive approach that includes a state-led sustainable industrial policy and restructuring of the coal mine industry.

\section{Lessons from the Turkish Coal Mining Industry}

The May 2014 mine collapse disaster at Soma that killed 301 mine workers provided impetus for the government's ratification of Convention No. $176 .{ }^{8,9}$ Operated by Soma Kömür İşletmeleri A.Ş, a private company, the disaster and subsequent public outrage highlights a key problem in the application of international labour standards: How do you close the gap between the rhetoric of global norms on worker safety and health with the reality of working conditions on-the-ground? Recognizing a new window of opportunity for long-term structural transformation and development in the coal mine industry, the ILO launched a special consultation with the Turkish government and social partners. ${ }^{10}$ The goal was to discuss how to apply international labour standards to protect occupational safety and health in conformity with the ILO supervisory system. In other words, how to apply global norms in a way that respects the range of obligations articulated by the ILO supervisory bodies. In response, the 
The ILO's Safety and Health in Mines Convention:

National Tripartite Meeting on Improving Occupational Safety and Health (OSH) in Mining was organized and hosted by the Turkish Ministry of Labour and Social Security in October 2014 with the ILO's technical experts facilitating. ${ }^{11}$

One result to emerge from this social dialog was a special technical assistance project to study the Turkish coal mining industry and occupational safety and health. The ILO and Turkey started the project in January 2015 and commissioned a major study to examine the industrial structure of the Turkish coal mining industry. ${ }^{12}$ The project was led by the ILO and TEPAV (The Economic Policy Research Foundation of Turkey). The final report is entitled "Contractual Arrangements in Turkey's Coal Mines: Forms, Extent, Drivers, Legal Context, and Impact on Occupational Safety and Health" and is to be released in 2016. In late 2015 the concluding recommendations section was released online through the ILO's website. ${ }^{13}$

The ILO-TEPAV study's core recommendation is a "sectoral development strategy for the coal industry" that takes into consideration Turkey's macro-level economic develop goals "with a long term vision" that "takes into account the occupational safety and health implications of such a vision." The goal of a "national policy on mining" should be "to enable a coordinated response to the need for an efficient continued development and use of Turkey's natural resources, all while ensuring optimal levels of safety and health of all persons engaged in the mining sector." This approach is noteworthy as a strategy for the application of international labour standards. As an ILO technical assistance project, it weaves together concern for labour and human rights norms with a recognition of the importance of an industrial policy emanating not from the private sector but from the state so as to safeguard basic human rights protections.

The ILO-TEPAV study makes nine specific policy suggestions. ${ }^{13}$ Each recommendation raises key issues about protecting safety and health in the Turkish mining industry. The nine recommendations can be read in light of the Turkish government's international obligation to apply, in practice, the Safety and Health in Mines Convention. Such a reading of these key points expands the general understanding of the national action that can be required to safeguard safety and health in accordance with ILO supervision of OSH-based international labour standards such as the Safety and Health in Mines Convention. Whereas most ILO standards require application of labour and employment law changes exclusively for a state to satisfy its international legal obligations under a given ILO convention, clearly, as we see with Turkey, some situations require significant state planning and industrial restructuring. Where legal changes are not enough to ensure respect, sustainable industrial policies should be seen as a component of ILO norms.

The Turkish case offers a real example of the need for a sustainable industrial policy to protect workers' rights and ensure nationwide compliance with fundamental labor and human rights obligations. These dynamics are illuminated within the Turkish coal mining sector itself and the associated challenges facing the Turkish state to ensure compliance with the Safety and Health in Mines Convention. Reading the need for state-led sustainable industrial policy into the ILO's supervision of OSH norms represents another avenue for the development of sustainable human rights protections. Such a reading also provides new points of leverage for Turkish social actors - inside or outside tripartite consultations. As the debate for reform and real change continues, major state-led industrial restructuring should be recognized as an integral component of a country's obligation under international labour and human rights conventions. This reading is especially important given the new international consensus on sustainable development.

\section{ILO-TEPAV Recommendations on Mine Sector Governance}

This section presents the nine policy recommendations released in late 2015 from the study "Contractual Arrangements in Turkey's Coal Mines: Forms, Extent, Drivers, Legal Context, and Impact 
Jeffrey Hilgert

on Occupational Safety and Health."13 This report, created through a year-long special ILO technical assistance effort and authored by ILO and TEPAV experts, recognizes the importance of addressing these recommendations in light of Turkey's obligations under the Safety and Health in Mines Convention and related global norms. Presentation of the report's policy recommendations is followed by a discussion of obligations under Convention No. 176 in an effort to pinpoint the obligation of stateled industrial policy.

Of the nine recommendations for reforming the regulation of Turkey's coal mines to ensure the protection of occupational safety and health, the majority-five recommendations-address broader sectoral governance challenges. The next three recommendations address more typical (but no less critical) legal issues in occupational safety and health regulation. A final falls into neither category and raises a contentious point in academic policy debates. Each recommendation has been developed after extensive consultation with domestic actors in Turkey and responds to unique challenges in the Turkish context. An analysis of these recommendations in light of the obligations of the Safety and Health in Mines Convention ${ }^{14}$ is presented after these recommendations.

\section{Sustainable Energy Policy}

Revise Turkey's energy policy taking into account sustainability principles. First among the nine recommendations is to "Revise Turkey's energy policy taking into account sustainability principles" to "shift from coal towards low-carbon renewable energy alternatives that are in harmony with the newly agreed international standards." This places the ILO's Safety and Health in Mines Convention firmly in the context of the new international consensus on energy and greenhouse gas emissions. The report notes that coal and lignite (or brown coal) was 30 percent of the national energy mix in 2014, and that Turkey remains 90 percent fossil fuel dependent. This dependence means Turkey has among the least sustainable energy sector in terms of greenhouse gas emissions. Between 1990 and 2013 these emissions increased around 110 percent according to TURKSTAT. Recommendation 1 notes how low carbon growth sits high on the international policy agenda and cites the Sustainable Development Goals $(\mathrm{SDGs})^{15}$ and the 2015 Paris Climate Change Agreement ${ }^{16}$ as new global norms. This view advises harmonizing Turkish energy policy with this new international consensus, a move that would likely have major implications for the transformation of the coal mining sector, the systemic pressures in the industry that now challenge strong safety protections, and how this sector contributes to the national energy supply.

\section{Sectoral Governance}

Revise the governance structure in the mining sector. The second recommendation of the ILO-TEPAV report calls for the reorganization of the governance structure of the coal industry. Turkey's Ministry of Energy and Natural Resources ${ }^{17}$ is currently responsible for ensuring a stable energy supply and mine licensing and "its primary obligation is to ensure that the electricity production is both affordable and timely." 13 This mandate "appears to relegate the operation of mines to a secondary level of importance" and "incentivizes increased risk taking in the coal mining sector." 13 The report recommends an institution-building effort to separate the responsibility of oversight of the coal mining sector from the Ministry of Energy and Natural Resources mandate for production. Alternative models are suggested to accomplish this including reorganizing the General Directorate of Mining Affairs (MIGEM) as an independent public board to oversee the coal mining sector. The objective is removing the incentive to "trade off" OSH standards and "ensure an improved governance structure and a smooth functioning of the coal industry with an improved occupational safety and health record." 13 
The ILO's Safety and Health in Mines Convention:

\section{Licensing Powers}

Ensure assessment and monitoring of compliance with OSH standards at the licensing stage. The conflicting institutional mandates of energy production versus broader worker protection goals in the coal mining sector extend to the government's licensing of mines. The Ministry of Labour and Social Security plays no role in assessing the safety and health conditions of mines at the licensing stage. As the recommendation noted, there is "a lack of consensus among the stakeholders regarding which institution should undertake this responsibility." 13 The General Directorate of Mining Affairs argues licensing is within its mandate and that "by law its mandate is to extend licenses all while ensuring that Turkey's mining reserves are utilized under the most efficient and rational principles, that the property rights as well as the environment are protected, and that the state's share is collected over the value added of production." ${ }^{13}$ This conflict of mandates ensures no pre-project evaluation of safety is completed before MIGGEM grants operating licenses. The recommendation asks for an occupational safety and health evaluation of mine operations before granting licenses. What is implied is that unsafe operations will not be licensed and will not be allowed to enter production, a policy control on the boundaries of the industry.

\section{Stakeholder Inclusion}

Redesign the sectoral governance structures to increase inclusiveness. In addition to a more sustainable energy policy, a more independent authority to regulate coal mining, and a successful OSH evaluation before granting operating licenses, a fourth recommendation concerns better sectoral social dialog processes.$^{18}$ One suggestion is to reorganize industry stakeholders to allow more input in designing new occupational safety and health policies. As the ILO-TEPAV report notes, rapid changes made to the law following the Soma tragedy left a range of social partners feeling that their expertise in the industry had not been adequately consulted in the design phase to amend the Law No 6631. ${ }^{13}$

\section{Rödövans Contracting}

Ensure that rödövans contracts and subcontracting arrangements are not misused and that fragmentation of responsibilities in regular subcontracting arrangements are addressed. The fifth recommendation from the ILO-TEPAV report addresses the rödövans contract system in the coal mining section, a unique problem in Turkey. The prevalence of the misuse of rödövans contracts in coal mining is not accurately known, but the role they play in the degrading of working conditions in the mine has been recognized by both NGOs and Turkish lawmakers. According to a Greenpeace report on the Soma mine disaster ${ }^{18}$ rödövans transfer management of coal mines from the state to private hands in exchange for an "amount on the tonnage of coal produced or the KW/hour of electricity produced through the production of coal." The system has been used by Turkish Coal Enterprise (TKI) and Electricity Generation Company (EÜAŞ) "to privatize coal fields under the condition of constructing a coal power plant and using the mined coal in electricity production." ${ }^{18}$ The legal bans on the use of rödövans contracts that have been introduced to date have been limited and have regulatory loopholes. For example, "state owned enterprises and their subsidiaries are exempt"18 despite a prohibition on their use by private companies.

This recommendation raises the question of identifying the prevalence of rödövans contracts "and other ambiguous and disguised subcontracting arrangements" in order to ascertain the impact it has upon the degradation of working conditions in the coal mining industry. The goal is building compliance with national occupational safety and health law and addressing the fragmentation of responsibility that is said to result from an industry operating based upon complex layers of subcontracting arrangements where the focus is largely on meeting contracted production targets with state authorities. The joint ILO-TEPAV report stops short of calling for the re-nationalization of the coal 
Jeffrey Hilgert

mining industry, a position taken by some Turkish trade unions to eliminate abuses in the rödövan contracting system. A recommendation calling for further study could imaginably conclude that such practices are incompatible with safety and health.

\section{Other ILO-TEPAV Recommendations}

Following the recommendations on sectoral governance and business structure of the coal mining sector, the remaining recommendations follow guidance more typical of the ILO's supervision of international labour standards. These recommendations focus upon legal compliance and applying recognized mine safety and health rights and protections in the convention. The first in this group is "Ensure that workers effectively can exercise their rights and that ambiguous recruitment systems are eradicated" and follows the observation that formal employment rates have declined in Turkish mining sector. ${ }^{13}$ The gang master system (Dayıbaş1lik) in the Soma basin is identified for further study, and coordinated training efforts are suggested, including through vocational schools, to ensure workers know their OSH rights. Other recommendations include improving "standardized first aid, search and rescue trainings" and to develop a "centralized database on national mining activities" to improve the reporting of "dangerous occurrences" in the mine sector as required by Convention No. 176. The final recommendation is to "explore the possibility" of establishing risk premiums through the mine worker accident insurance system so as to determine the insurance premiums in accordance with each mine's risk evaluation. The objective is to create financial incentives in the industry for investment in OSH prevention. This is a common idea in the insurance industry, but the application of these principles to employment injury benefits systems has been questioned by some unions and researchers for incentivizing the under reporting of injuries. ${ }^{19}$

\section{The Scope of Obligations under Convention No. 176}

The ILO's regular system of supervision remains an important process for monitoring the application of international labour standards. While the International Labour Office provides expert technical assistance to aid countries in the application of the conventions they ratify, it is the ILO's Committee of Experts on the Application of Conventions and Recommendations ${ }^{20}$ that interprets the meaning of these ratified conventions. The Safety and Health in Mines Convention falls under this category for ILO supervision.

Thirty-one ILO member-states have ratified the Safety and Health in Mines Convention. ${ }^{21}$ The Turkish case is unique and raises several important questions about the obligations to establish a sustainable industrial policy on coal mining under the Safety and Health in Mines Convention. Given the international policy developments on sustainability since the adoption of Convention No. 176 in 1995 and the impact of coal mining on energy policy and the degradation of environmental safety and health, there is a strong justification for the viewpoint that obligations require the development of stateled industrial policies under the ILO's Safety and Health in Mines Convention. The ILO-TEPAV recommendations describe how a more sustainable national energy strategy is needed to help the country meet its international obligations on sustainable development and low-carbon futures as well as occupational safety and health protection. The recommendations also raise serious questions about the rödövans contract system and how it may be a system that inherently degrades working conditions. The ILO-TEPAV recommendations on the sectoral governance and business structure of the mine sector altogether raise an important question about the obligation to develop state-led industrial policies that are consistent with global norms on sustainability, human rights, and the protection of worker safety and health.

Historically the ILO Committee of Experts has focused on legal provisions and ensuring that ILO norms are realized in law and practice. ${ }^{20}$ When health and safety protection unfolds in an industry 
The ILO's Safety and Health in Mines Convention:

structured in a way that inherently degrades working conditions, realizing the protection of safety and health in practice under ILO norms may require state-led industrial policy to restructure business models. Such state-led industrial policy could take many forms, but what is important to note is how, in the case of the Turkish coal mining industry, is how such obligations can be read as being a part of the obligations of the ILO-OSH norms such as Convention No. 176, the Safety and Health in Mines Convention.

Grounding such a reading in the text of the Safety and Health in Mines Convention could be done in various ways. One such grounding could be argued through the obligations set forth in Article 3 of Convention No. 176. Article 3 addresses the obligation to develop a coherent national mine OSH policy.

"Article 3. In the light of national conditions and practice and after consultations with the most representative organizations of employers and workers concerned, the Member shall formulate, carry out and periodically review a coherent policy on safety and health in mines, particularly with regard to the measures to give effect to the provisions of the Convention." 14

Article 3 requires a policy be developed "in the light of national conditions and practice" and therefore responding to unique national conditions. Developing a coherent national policy on safety and health in mines requires integrating knowledge of these systemic practices into the national policy. Adopting a cookie-cutter OSH policy statement without a strong grounding that responds to national conditions and practices in the mine industry cannot be considered coherent. On the question of Turkish national conditions and practices, the ILO-TEPAV report notes a complex challenge on energy policy, ownership structure, business contracting, and the protection of safe and healthy working conditions in coal mining.

\section{Elaborating a coherent policy on safety and health in mines}

The Committee of Experts at the ILO has made ten observations related to the application of the Safety and Health in Mines Convention. ${ }^{21}$ Their most recent observation of the application of Article 3 concerned mine safety in Peru and raised the manner in which a coherent national policy on safety and health is formulated. To the Committee of Experts, such a coherent national policy must be formulated, implemented and periodically revised "particularly in relation to measures to give effect to the provisions of the Convention" and "taking account the conditions and practices in the country" after consultation with social partners. The committee is not satisfied that only a general national policy on occupational safety and health had been adopted and applied to the mine industry; no specific policy on safety and health in mines had been drafted. In this case, a coherent policy on safety and health in mines was interpreted as a specific policy on safety and health targeted specifically at the mining industry. ${ }^{22}$

Other notable observations emphasize the necessity that a coherent national policy on safety and health "give effect to the provisions of the convention." These observations outline a clear interpretation that this policy must (1) focus exclusively on the mine sector, and (2) ensure that the convention itself through its related rights and provisions is applied in practice. This means that such a safety and health policy for the mine industry could not be considered coherent if it does not focus specifically on the mine sector and articulate strategies to effectuate the convention in response to national conditions and practice.

In some cases, failing to take a larger industrial policy approach on mine safety and health can challenge the success of safety and health regulations. The rödövans contract system, for example, 
Jeffrey Hilgert

clearly is an issue of importance to protecting the safety and health of workers. Developing a national policy on safety and health in mines without addressing this practice certainly lacks coherence given the evidence regarding how this system can incentivize dangerous conditions and a degradation of work. The Soma case is one example of this. ${ }^{18}$ State-led industrial restructuring could in some cases be justified under Article 3 of the Safety and Health in Mines Convention as a coherent and responsive policy is required.

State-led industrial policy restructuring, including perhaps public ownership of the mines, could be considered a necessary solution in some circumstances. Every national situation is different, however. The obligations assumed under Convention No. 176 must respond to the national conditions and practices, so making a blanket policy prescription runs counter to the obligations of the convention. Industrial policy action might very well be the solution for some countries, while in other countries traditional labour and employment law may provide adequate worker protection. The decision may turn on the structure of the industry itself, the nature of the well-entrenched private interests that exist in the mine sector, and how these structures combine to degrade working conditions and the viability of more traditional worker health and safety protections through classic legal enactments and enforcement. One could imagine an industry so rife with a culture of disregard for worker safety and health that the only pragmatic way to give effect to the provisions of the Safety and Health in Mines Convention would be aggressive state restructuring of the mine industry, perhaps even including the nationalization of segments of the extractive sector entirely.

In "giving effect to the provisions of the Convention" the obligations require the protection of a wide range of rights at work in the mine sector. Workers have the right to participate in inspections, and must have recourse to independent experts and adequate training. Workers must also have a right to refuse the assignment of dangerous work. Employers have the obligation to coordinate occupational safety and health practices where there are two or more employers and they are required to provide adequate training on safety and health matters. Governments hold obligations as well, such as establishing national laws and regulations to supervise safety and health in mines and provide for a system of inspection. These are just some of the provisions in Convention No. 176, a norm focused on creating a comprehensive infrastructure of legal protection centered on regulating the employment relationship and working conditions in mining. The necessity of a cohesive national policy thus must respond to the complexity of national conditions.

\section{Convention No. 176 and the New Global Consensus on Sustainability}

While an argument has been outlined here regarding the need for state-led industrial policy action under Article 3 of the ILO's Safety and Health in Mines Convention, an equally profound challenge remains concerning how to link this critical standard to the new global consensus on sustainability. Continuing with a contemporary reading of the Article 3 obligation to carry out a dedicated coherent policy to give effect to the convention, we can raise the following question: Can a national policy on safety and health in mining be recognized as coherent if the policy is not consistent with a country's sustainability obligations? Convention No. 176 grants authority "to suspend or restrict mining activities on safety and health grounds, until the conditions giving rise to the suspension or restriction has been corrected" (Article 5(2)(e)). ${ }^{14}$ State power clearly exists to restrict or shutter operations where occupational safety and health protections cannot be satisfied. How far should state authority be extended on the broader question of human health?

Within the Turkish context, the ILO-TEPAV report ${ }^{13}$ recommends that such global safety and health norms must be implemented in light of the overall normative obligations at play in the international system. For the coal mining industry in Turkey, this may mean recognizing the hazards posed by climate change by continuing a low-cost carbon intensive energy policy, yet international commitments that have been undertaken to move global society towards a low-carbon future. Does this 
The ILO's Safety and Health in Mines Convention:

mean that a cohesive national policy under the Safety and Health in Mines Convention also requires a policy for the elimination or at least the controlled reduction of coal mining? Reading across normative human rights documents and understanding the relationship between different international obligations can help to answer this question.

The UN Human Rights Council recognized the serious threat to the protection of all human rights from climate change in Resolution 7/23 adopted on 28 March 2008: "climate change poses an immediate and far-reaching threat to people and communities around the world and has implications for the full enjoyment of human rights," the Council explained. ${ }^{23}$ Similarly, the Framework Convention on Climate Change asks parties "when taking action to address climate change" to "respect, promote and consider their respective obligations on human rights." ${ }^{24}$ The Vienna Declaration and Program of Action, adopted at the World Conference on Human Rights in 1993, defends a similar notion of the interconnectivity between rights. "All human rights" the declaration notes "are universal, indivisible and interdependent and interrelated" and thus "it is the duty of States, regardless of their political, economic and cultural systems, to promote and protect all human rights and fundamental freedoms." ${ }^{25}$

The challenge posed by society's new sustainability consensus would appear to confound longterm protection of workers' human rights in a carbon-intensive industry such a coal mining. Yet given the new global sustainability consensus, a material such as coal should be controlled and cleaner sources of energy should be developed. What consequences does this apparent conflict have for the development and application of a cohesive national policy on occupational safety and health in the mines? Are we correct to follow our common patterns of consciousness and treat both global sustainability policy and global worker health policy as two distinct and irreconcilable human rights concerns, however critical one may think both concerns may be in their own respective domains? How does one conceptualize a coherent linkage?

Regardless of how one ultimately conceptualizes a coherent linkage, a coherent linkage must be made. The protection of the human right to just and favorable working conditions in mining today must be recognized. The entrenchment of carbon intensive industries, however, cannot be justified at the expense and the enjoyment of the human rights of all people in the future. The movement toward more sustainable economics will raise significant human rights issues going forward. Human rights issues must be openly addressed as more sustainable development practices are implemented. These issues cannot be ignored in the development of cohesive national policies on safety and health in mine work. There is a relationship between safety and health in mines and business models that incentivize dangerous work practices. These dangerous business models can be seen as disregarding environmental hazards of all kinds. Creating any manner of cohesive national policy for safety and health in mine work must encompass the broader range of environmental hazards posed by the industry. Limiting OSH policy to a narrow range of legal changes is simply inadequate as a strategy for developing a cohesive policy as is called for by these global norms.

\section{Conclusion: Reframing the Scope of Obligations for the Contemporary Context}

Given the need for parties to Convention No. 176 to develop a specific and cohesive policy on safety and health in mine work that is responsive to national conditions, there is a serious need to modernize the scope of the obligations required under this global norm for the contemporary global context. In light of the new global consensus on sustainability, but also in light of the evident need for state-led industrial policy restructuring in certain national contexts like Turkey, no cohesive policy can be developed without a deeper understanding of the relationship between mine industries like coal, sustainable energy policies and how business structures in the industry may be inherently dangerous for workers' occupational safety and health now and in the future. These issues obligate significant structural reform led by activist state action. Any policy that does not at least respond to the relationship 
Jeffrey Hilgert

between these factors should not be considered to be a "cohesive policy" for the purposes of Article 3 of the ILO's Convention No. 176.

Public demands from civil society, trade unions and others have urged the improvement of working conditions for mine workers worldwide at the same time as the development of more sustainable low-carbon energy policies. On the occasion of the Safety and Health in Mines Convention's $20^{\text {th }}$ birthday as the global charter of mine workers' health and safety rights, the convention itself must be understood in the changing context of contemporary society, not in the frozen state of the world as it was in 1995 when the text was adopted by the International Labour Conference. Social actors pressing for stronger changes and just transitions for environmental protection could advocate for a broader reading of the convention, a reading that requires policy action on sustainability and industrial restructuring to protect human rights.

\section{Notes}

1. Convention (No. 176) concerning safety and health in mines. Adopted at the $82^{\text {nd }}$ Session of the International Labour Conference held on 22 June 1995 in Geneva. 2029 U.N.T.S. 207 (1995).

2. International Federation of Chemical, Energy, Mine and General Workers' Unions (2010). The Stronger the Union, The Safer the Mine: How to Use Convention No. 176, A Campaign Guide. Geneva: International Federation of Cheminal, Energy, Mine and General Workers' Unions.

3. Convention (No. 167) concerning safety and health in construction. Adopted at the $75^{\text {th }}$ Session of the International Labour Conference held on 20 June 1988 in Geneva. 1593 U.N.T.S. 33.

4. International Labour Office. 2011. World Congress calls for a renewed commitment to build a preventative safety and health culture. Press Release, September 15. Accessed online at http://www.ilo.org/global/about-the-ilo/press-and-media-centre/news/WCMS_162921/lang--en/index.htm.

5. Istanbul Declaration on Safety and Health at Work. 2011. Signed at Istanbul September 11, during the World Congress on Occupational Safety and Health. Described in Hilgert, Jeffrey. 2012. "The Future of Workplace Health and Safety as a Fundamental Human Right" in Comparative Labour Law and Policy Journal. 34:715.

6. Convention (No. 155) concerning occupational safety and health and the working environment. Adopted at the $67^{\text {th }}$ Session of the International Labour Conference held on 22 June 1981. 1331 U.N.T.S. 22345.

7. NSNBC International. 2014. Private Turkish Mines Known As Death Traps. International Edition. Online at nsnbc.me/2014/05/15/private-turkish-mines-known-as-death-traps/

8. Evyapan, Fatma. 2015. Coal Mining in Turkey: State and Private Sector Interactions Subcontracting and Redevance. Turkish Thoracic Journal, 16(Supplement 1):3-4.

9. Atalay, Figen. 2015 The History of the Coal Mining Industry and Mining Accidents in the World and Turkey. Turkish Thoracic Journal, 16(Suppl 1):5-8.

10. International Labour Office. 2015. World OSH Day Celebrated in Turkey for the First Time. Press Release, 28 April. Accessed online at http://www.ilo.org/ankara/news/WCMS_373444/lang--en/index.htm.

11. International Labour Office. 2014. Government, workers' and employers' representatives agreed on the main elements of a roadmap on OSH in mines. Press Releaase, 17 October. Accessed online at http://www.ilo.org/global/about-the-ilo/media-centre/press-releases/WCMS_315255/lang--en/index.htm.

12. International Labour Office. 2015. Recent study launched by ILO and TEPAV calls for the development

of a national policy on mining. Press Release, 18 December. Accessed online at http://www.ilo.org/ankara/news/WCMS_437137/lang--en/index.htm.

13. ILO-TEPAV. 2015. Contractual Arrangements in Turkey's Coal Mines: Forms, Extents, Drivers, Legal Drivers and Impact on $\mathrm{OSH}$. Accessed online at www.ilo.org/wcmsp5/groups/public/---.../wcms_437141.pdf.

14. Convention (No. 176) concerning safety and health in mines. Adopted at the $82^{\text {nd }}$ Session of the International Labour Conference held on 22 June 1995 in Geneva. 2029 U.N.T.S. 207 (1995).

15. Sachs, Jeffrey D. 2012. From millennium development goals to sustainable development goals. The Lancet, 379(9832):2206-2211.

16. Jenkins, Chris. 2016. Reframing health for COP21, Paris 2015. Journal of Public Health Policy, 37(1):123-125.

17. T.C. Enerji ve Tabii Kaynaklar Bakanlı̆̆ı. 2015. Http://www.enerji.gov.tr/tr-TR/Anasayfa. 
18. Pınar Aksoğa, Deniz Bayram and İbrahim Çiftçi. 2015. Soma Coal Mine Disaster Information Report. Greenpeace Mediterranean. Accessed online at http://priceofoil.org/content/uploads/2014/06/Soma-Coal-MineDisaster-Report-GPMED.pdf.

19. Mansfield, Liz, Ellen MacEachen, Emile Tompa, Christina Kalcevich, Marion Endicott and Natalie Yeung. 2012. A critical review of literature on experience rating in workers' compensation systems. Policy and Practice in Health and Safety, 10(1):3-25.

20. Gravel, Eric and Chloé Charbonneau-Jobin. 2003. The Committee of Experts on the Application of Conventions and Recommendations: Its Dynamic and Impact. International Labour Office.

21. International Labour Office. 2015. NORMLEX Information System on International Labour Standards [accessed 15 October]. Available online from: http://www.ilo.org/normlex.

22. The Committee of Experts on the Application of Conventions and Recommendations. Observation on Peru under Convention No. 176. NORMLEX Information System on International Labour Standards. Available online from: http://www.ilo.org/normlex.

23. United Nations Human Rights Council. 2008. Resolution 7/23 on Human rights and climate change. Adopted at the 41st Meeting of the UN Human Rights Council in Geneva.

24. Conference of the Parties, Twenty-first session (COP21). 2015. Framework Convention on Climate Change. Adopted in Paris on 11 December. United Nations FCCC/CP/2015/L.9.

25. World Conference on Human Rights. 1993. Vienna Declaration and Programme of Action. Adopted in Vienna on 12 July. United Nations Doc. A/CONF.157/23. 